\title{
Antimicrobial activity of phenolic compounds isolated from Caesalpinia pulcherrima
}

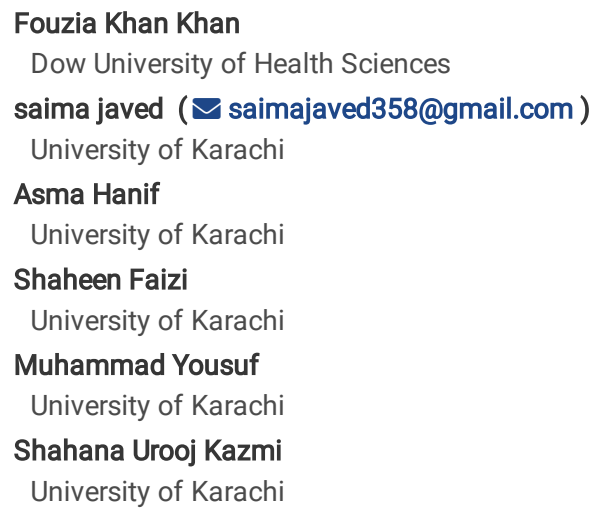

\section{Research}

Keywords: Caesalpinia pulcherrima, anti-microbial activity, synergistic combinations, Methyl gallate, Ciprofloxacin, Amoxycillin, Gallic acid

Posted Date: January 28th, 2021

DOI: https://doi.org/10.21203/rs.3.rs-154525/v1

License: @ (i) This work is licensed under a Creative Commons Attribution 4.0 International License. Read Full License 


\section{Abstract}

Introduction

Multidrug resistance is an alarming issue worldwide. Herbal plants are being used as therapeutic agents since ages. One such plant is Caesalpinia pulcherrima, known for its beneficial effects. Therefore, this study was planned to isolate pure compounds and check its antimicrobial activity along with synergism.

Methodology

Antimicrobial susceptibility pattern of MDR clinical bacterial strains against phenolic compounds was performed by Agar well diffusion method. Minimum inhibitory concentration (MIC) was determined by tube dilution and micro broth dilution methods. Synergistic combinations of Methyl gallate with antibiotics were assessed by checkerboard titration method. Scanning Electron Microscopy was conducted to analyse the changes in cell morphology of MDR E. coli and Methicillin-Resistant Staphylococcus aureus after treatment with Methyl gallate

Results

Methyl gallate showed promising antimicrobial activity $(250-500 \mu \mathrm{g} / \mathrm{ml})$, whereas, Ethyl gallate, Syringic acid and Gallic acid trimethyl ether showed MIC $(500-2500 \mu \mathrm{g} / \mathrm{ml})$. Time kill kinetics assays of Methyl gallate showed bactericidal activity. Methyl gallate showed good synergistic combinations with Amoxycillin and Ciprofloxocin. Scanning electron microscopy of Methyl gallate depicted profound disruption in the cell wall, incomplete cell division and distorted structure of MDR bacteria.

\section{Conclusions}

Phenolic compounds were found to be a potential source of therapeutic substances as compared to the conventional antibiotics. Further studies are required to explore their mechanism of action.

\section{Introduction}

The discovery of antibiotics is one of the greatest achievements in the history of medical sciences. Antibiotics are not only involved in the treatment of infections but also for the assurance of successful surgical interventions [1]. Despite all the facts regarding their effectiveness, the evolution of resistance against antibiotics is a distressing issue. Natural resistance was found in some bacteria even before the invention of antibiotics. There are many factors associated with the emergence of resistance such as mutations in microbes, inappropriate use and over the counter sale of antibiotics. Herbal medicine has been in use in the treatment of various diseases since ages [2]. It has been reported that more than $80 \%$ of world's population depends on herbal medicine for various illnesses [3]. There is a rich history of utilization of herbal medication and transfer of knowledge from generation to generation. The WHO has been involved in collecting and documenting the benefits of herbal medicine from the natives of different cultural backgrounds [4]. Many studies have been and are conducted on plants to authenticate the claim of their use in herbal medicine. Health benefits of medicinal plants are due to the presence of secondary metabolites called phenolic compounds [5]. The benefits of these compounds are related to their consumption as food and their bioavailability [6]. Caesalpinia pulcherrima is an ornamental plant, inhabitant to Central America but also found in Africa, Asia and Australia [7]. Extracts from different parts of the plant have been used as anti-convulsant, anti-inflammatory and immuno-stimulating agents [8]. The stem was found to be useful as an abortifacient and antiulcer agent [9]. The idea of synergy between herbal drugs and antibiotics is a new approach to treating multidrug-resistant bacteria. Antimicrobial activity of extracts of different parts of this plant has been explored in our previous study [10]. After obtaining promising results, we planned this study and isolated pure compounds from fresh pods and performed antimicrobial activity against MDR (multi-drug resistant) bacteria alone and in combination with antimicrobials and also checked its effect on bacterial cell morphology.

\section{Materials And Methods}

\section{Preparation of plant extracts and isolation of Pure Compounds}

The methanol extract of pods (CP-Pods-M 292gms) was subjected to solvent separation which gave hexane (P.E), ethyl acetate (EA), butanol (But) and aqueous ( $\mathrm{Aq})$ phases separately. A small quantity $(1.6 \mathrm{~g})$ of EA phase $(35.6 \mathrm{~g})$ was fractionated using different ratios of PE:EA mixture, which led to the isolation of a pure compound in one of the above fractions (PE:EA 1:1), identified as methyl gallate through spectral studies. Major quantity of EA phase (34.0 g) was subjected to VLC, which afforded 23 fractions. The fraction VLC- 5 afforded Methyl-4-hydroxy benzoic acid, Fraction VLC- 6 afforded Ethyl gallate, Fraction VLC- 7 and VLC-8 afforded methyl gallate in large quantity (1.4\% wet weight base), while fraction 9 was found to be a mixture of methyl gallate and gallic acid. Based on this work, phenolic compounds (Dodecyl gallate, Propylgallate, Vanillic acid, Syringic acid, Ethyl-4 hydroxy benzoic acid, Gallic acid trimethyl ether) obtained commercially were used in the present study.

\section{Antimicrobial Activity of Plants and Phenolic compounds}

Antimicrobial activity of phenolic compounds (Gallic acid, Methyl gallate, Ethyl gallate, Propyl gallate, Dodecyl gallate, Syringic acid, Vanillic acid, Para hydroxybenzoic acid, Methyl 4 hydroxy benzoic acid, Ethyl 4 hydroxy benzoic acid, Gallic acid trimethyl ether) was checked against MDR clinical bacterial isolates and ATCC reference strains. Antimicrobial susceptibility pattern of MDR clinical bacterial strains against phenolic compounds was assessed by Agar well diffusion method [11]. Minimum inhibitory concentration (MIC) was determined by tube dilution and micro broth dilution methods [12].

\section{Agar Well Diffusion Method}


Antimicrobial activity of phenolic compounds was tested against MDR clinical pathogen by agar well diffusion method. The stock solution of all plant extracts was prepared in sterile DMSO. The overnight grown culture was inoculated in Mueller Hinton Broth, incubated for 3-4 hours in aerobic conditions at $37^{\circ} \mathrm{C}$ to get a log phase culture. The turbidity of culture was matched with 0.5 Mac Farland index. Mueller Hinton Agar plates were seeded with bacterial culture. $20 \mu \mathrm{l}$ of extracts were added in the wells (diameter $=6 \mathrm{~mm}$ ) made by sterile borer and incubated for 24 hours at $37^{\circ} \mathrm{C}$ in aerobic conditions. Results were recorded by measuring zones of inhibition around wells. The experiment was run in triplicate on three different occasions

\section{Minimum Inhibitory Concentration By Micro broth Dilution Method}

Phenolic compounds as well as conventional antibiotics that lost efficacy were checked to determine their MIC. Two-fold serial dilutions of extracts, fractions, phenolic compounds and conventional antibiotics were prepared in Mueller Hinton broth in 96-well flat bottomed plates. $20 \mu \mathrm{l}$ of inoculums $10^{6} \mathrm{CFU} / \mathrm{ml}$ were added in each well to keep a total volume at $200 \mu \mathrm{l}$. Micro titer plates were incubated at $37^{\circ} \mathrm{C}$ for 24 hours. Dilution with no turbidity was considered as MIC. The experiment was run in triplicate on three different occasions.

\section{Minimum Inhibitory Concentration By Tube Dilution Method}

MIC of phenolic compounds as well as conventional antibiotics was reconfirmed by tube dilution method. $1 \mathrm{ml}$ MH broth was added in sterile test tubes with inoculums $\left(10^{6} \mathrm{CFU} / \mathrm{ml}\right)$. Tubes without extracts but containing $\mathrm{MH}$ broth and inoculum were designated as positive control, whereas negative control had extract and $\mathrm{MH}$ broth.

\section{Minimum Bactericidal Activity:}

$\mathrm{MBC}$ was determined by taking $100 \mu \mathrm{l}$ of MHB from the wells and tubes containing plant extracts showing no apparent turbidity and subcultured on MHA plates. The lowest concentration without any growth was considered as MBC value [13].

\section{Time Kill Kinetics Assay:}

Time Kill Kinetics was performed to study the effect of pure Methyl gallate on the growth of MDR bacterial isolates [14]. MRSA $(n=10)$, MDR E. coli $(n=10)$ and control ATCC cultures of $S$. aureus and $E$. coli were selected for this study. $20 \mathrm{ml}$ cation adjusted MHB with the absolute concentration of $0.5,1$ and $2 \times$ MIC of Methyl gallate. The log phase culture of bacteria with the inoculums $10^{5} \mathrm{CFU} / \mathrm{ml}$ was transferred to the flask. The flask was incubated for 24 hours at $37^{\circ} \mathrm{C}$. $100 \mu \mathrm{l}$ was taken from the flask and plated on MHA at 2,4,6,8 and 24 hours time interval. The plates were further incubated for 24 hours at $37^{\circ} \mathrm{C}$ to check $\mathrm{CFU} / \mathrm{ml}$. The experiment was run in replicate on three different occasions.

\section{Antimicrobial activity of Methyl gallate with Ciprofloxocin and Amoxycillin:}

The emergence of multidrug resistance is on the rise; therefore, there is an urgent need for exploring alternative therapeutic regime, which may include a combination of plant-derived substances with antibiotics that have lost efficacy. In the present study, different combinations of Amoxycillin and Ciprofloxocin with Methyl gallate were studied by checkerboard titration method as demonstrated in earlier study [15]. The assay was performed in flat bottomed sterile 96 well-bottomed plate. Methyl gallate with its two-fold serial dilutions was performed in all rows. Dilutions of antibiotics were made in separate test tubes. Antibiotics with their dilutions were added to all columns with equal quantity. Each well of 96 well plate had same combinations of compound and antibiotics. Inoculum size was adjusted to $10^{6} \mathrm{CFU} / \mathrm{ml}$ in each well. The highest concentration of Ciprofloxocin and Amoxycillin was $650 \mu \mathrm{g} / \mathrm{ml}$ and $325 \mu \mathrm{g} / \mathrm{ml}$, respectively. Moreover, the highest concentration of Methyl gallate was $500 \mu \mathrm{g} / \mathrm{ml}$. Fractional Inhibitory concentration index (FICl) was measured as the sum of MIC of agent with combination divided by MIC of agent alone. Results of FICl were evaluated as synergy $=\leq 0.5$, additive effect $=>1$ to 2 , no effect or antagonism $=>2$.

Effect of Methyl gallate isolated from C. pulcherrima on Morphology of Bacterial Cells by Scanning Electron Microscopy (SEM):

In order to study the effect of subinhibitory concentrations of Methyl gallate on bacterial cell morphology by SEM, MRSA and MDR, E. coli was grown in MH broth with $0.5 \mathrm{MIC}$ of compound for 24 hours at $37^{\circ} \mathrm{C}$. After incubation, the cells were washed thrice at $10000 \mathrm{rpm}$ with sterile deionised water and resuspended in PBS. A drop of culture was fixed with ethanol on $4 \mathrm{~mm}$ glass slides. Negative staining was performed with $0.2 \%$ uranyl acetate for 30 seconds. Results were observed under GOEL JEM 1200 EX II Electron Microscop

\section{Results}

\section{Methyl gallate:}

Methyl gallate isolated from C. pulcherrima was found to be a potent antimicrobial substance against S. typhi ATCC 27853, MRSA, S. aureus ATCC 29213 MDR E. coli and

K. pneumoniae $(\mathrm{MIC}=125 \mu \mathrm{g} / \mathrm{ml})$. However, antimicrobial activities against remaining clinical bacterial isolates were in the range of $250-500 \mu \mathrm{g} / \mathrm{ml}$ as shown in Table 1A, 1B.

\section{Phenolic Compounds:}

Gallic acid exhibited lower MIC (500 $\mu \mathrm{g} / \mathrm{ml})$ against MRSA, S. aureus ATCC 29213,

S. typhi, S. typhi ATCC $27853, K$. pneumonia, E. coli and E. coli ATCC 25922. Ethyl gallate displayed MIC (500 $\mu \mathrm{g} / \mathrm{ml})$ against MDR E. coli and E .coli ATCC 25922. Syringic acid and Gallic acid trimethyl ether showed MIC $(500 \mu \mathrm{g} / \mathrm{ml})$ against S. typhi ATCC 27853 . Dodecyl gallate, Propyl gallate, Vanillic acid, 
Parahydroxy benzoic acid, Ethyl 4 hydroxy benzoic acid and Methyl 4 hydroxy benzoic acid failed to show antimicrobial activity against MDR clinical bacterial isolates as shown in Table 1A, 1B.

\section{Effects of Methyl gallate on Growth Kinetics of MDR Bacteria:}

Time kill kinetics of gram-positive bacteria MRSA and S. aureus ATCC 29213 and gram-negative bacteria MDR E. coli and E. coli ATCC 25922 was carried out to study the effect of Methyl gallate on their growth. Ten strains $(n=10)$ of each species were included in this study. MRSA and S. aureus ATCC 29213 showed a reduction of CFU within 2 hours and complete bactericidal activity was observed at 24 hours and 6 hours, respectively at MIC and $2 \times$ MIC. Moreover, at $0.5 \times$ MIC, bacterial count was reduced at 5 hours in MRSA. In case of S. aureus ATCC 29213, a steady decline in CFU till 6 hours and then an increase in bacterial count were noticed (Fig. 1,2).

Figure 3 shows concentration-dependent fall in CFU of E. coli ATCC 25922, less than the MIC showed lag phase for 4 hours and then started to fall between 4 to $6 \mathrm{hrs}$, and again multiplied. At MIC and $2 \times \mathrm{MIC}$, a drastic reduction in growth was recorded after 2 hours and complete bactericidal activity after 6 hours of post-incubation. Figure 4 shows a slight reduction in CFU of MDR. E. coli was noticed in culture treated with 0.5 MIC to 5 hours. Culture grown in $2 \times$ MIC showed complete inhibition of growth after 8 hours. At MIC inhibition, bacterial growth was observed till 8 hours and cidal activity was noticed at 24 hours.

Figure \#5 shows prominent structural changes in the cell wall of MDR E. coli. The surface of the cell was rough, disrupted with expulsion of cell contents. Arrow indicated the appearance of depression on the surface of the cell (C). Incomplete cell division and septum formation were also noticed as shown by arrows (D). There was a significant malformation, typical long rod shape converted into small rods and cocci. Morphological changes in MRSA after treatment with Methyl gallate are shown in Fig. 6. Overall, the size of cells was bigger with a distorted surface (C and D) as compared to untreated cells (A and B). Septum formation was as indicated by arrow leading to incomplete separation of daughter cells (D and E).

\section{Antimicrobial Activity of New Synergistic Combinations of Methyl gallate:}

In order to develop efficient therapeutic combinations against MDR bacterial isolates, Methyl gallate, a phenolic compound isolated from $C$. pulcherrima, in combination with commonly used conventional antibiotics was evaluated for its antimicrobial activity.

\section{Synergistic Combinations of Ciprofloxocin with Methyl gallate:}

When synergistic combinations of Methyl gallate and Ciprofloxacin were tested against MDR E.coli, there was a significant reduction of MICs of Ciprofloxocin and Methyl gallate from $512 \mu \mathrm{g} / \mathrm{ml}$ to $0.125 \mu \mathrm{g} / \mathrm{ml}$ and $500 \mu \mathrm{g} / \mathrm{ml}$ to $15.6 \mu \mathrm{g} / \mathrm{ml}$, respectively. However, MICs of Ciprofloxacin were still higher than the breakpoint values. Average $\mathrm{FICl}$ (fractional inhibitory concentration index) was $(0.137 \pm 0.11)$ suggesting good synergism between the two combinations. MIC of Ciprofloxacin failed to reach its breakpoint, therefore, no zone of inhibition around Ciprofloxacin disc placed in MHA incorporated with ( $0.2 \times \mathrm{MIC})$ of Methyl gallate was observed (Table 2).

\section{Synergistic Combinations of Amoxycillin with Methyl gallate:}

A synergistic combination of Amoxicillin and Methyl gallate was observed against MRSA, with a remarkable fall in MICs of Amoxycillin and Methyl gallate from $256 \mu \mathrm{g} / \mathrm{ml}$ to $0.0625 \mu \mathrm{g} / \mathrm{ml}$ and $500 \mu \mathrm{g} / \mathrm{ml}$ to $31.25 \mu \mathrm{g} / \mathrm{ml}$, respectively. Sub-inhibitory concentration $(0.2 \times$ MIC) of Methyl gallate was incorporated in MHA plate. $10 \mathrm{~mm}$ zone of inhibition of Amoxicillin was noted and compared with control MHA plates. Average $\mathrm{FICl}(0.225 \pm 0.162)$ exhibited potent synergistic antimicrobial combination (Table 3).

\section{Discussion}

Multi drug-resistant bacterial infections are responsible for greater portion of infectious disease burden worldwide. For the last twenty years, the emergence of antimicrobial resistance along with the adverse effects of antibiotics has directed the researchers for the exploration of new antimicrobial substances specifically from herbal extracts, which can be able to solve the above problems [1]. Moreover, the therapeutic potential of herbal plants has been studied and identified to use them as a source of new drugs. According to the guidelines of WHO in 1997, beneficial plants can be used as an alternative of drugs [2].

During the course of the study, different clinical samples were collected from patients suffering from a variety of infections. These samples were processed for isolation of MDR human pathogens, which were screened against different antibiotics in order to determine their antibiotic susceptibility pattern. Methyl gallate exhibited remarkable antimicrobial activity against both MDR gram-positive (MIC $=250 \mu \mathrm{g} / \mathrm{ml})$ and gram-negative bacteria $(\mathrm{MICs}=125-250 \mu \mathrm{g} / \mathrm{ml})$. According to one study, phytochemicals with MIC between $100-1000 \mu \mathrm{g} / \mathrm{ml}$ are considered as potential antimicrobial agents [3]. Earlier reports stated the antimicrobial activity of Methyl gallate against MRSA with (MIC $=1.25 \mathrm{mg} / \mathrm{ml}$ ) [4,5]. MRSA is one of the most important pathogens that accounts for respiratory tract, skin, and surgical site infections with high mortality and morbidity [6]. Previous studies indicated the antimicrobial activity of Methyl gallate against non-MDR E. coli, S. typhi and Vibrio Cholerae [7, 8]. Time kill kinetics study of Methyl gallate showed dose-dependent bactericidal activity in both gram-negative and gram-positive bacteria. Profound effects of Methyl gallate on cell morphology of MRSA and MDR E. coli were seen by Scanning Electron Microscopy. Disruption in cell wall, incomplete cell division and distorted structure suggested that the site of action of Methyl gallate was cell wall.

Gallic acid showed antimicrobial activity $(\mathrm{MIC}=500-1000 \mu \mathrm{g} / \mathrm{ml})$ in the current study, whereas, previous study endorsed our results [9]. Antimicrobial activity of Gallic acid was observed in one study with $(\mathrm{MIC}=100 \mu \mathrm{g} / \mathrm{ml}, 1100 \mu \mathrm{g} / \mathrm{ml}, 1250 \mu \mathrm{g} / \mathrm{ml})$ against non- MDR E. coli, P. aeruginosa and S. aureus, respectively [10]. Moreover, Ethyl gallate showed antibacterial activity against MDR E. coli and E. coli ATCC $25922(\mathrm{MIC}=500 \mu \mathrm{g} / \mathrm{ml})$. Another study supports the findings of our research work [5].

It was reported that the antimicrobial activity of alkyl esters of GA depends on specific lipophilic characteristics, assuming that cytoplasmic membrane could be a possible site of action. There are various modes of actions regarding the antimicrobial activities of phenolic compounds including interaction with including sulfhydryl group, change in permeability of cytoplasmic membrane, inactivation of enzymes, insoluble complexes with amino acids and proteins. 
One more study explained the antibacterial activity of Ethyl gallate against $P$. aeruginosa ATCC 27853 [10]. However, Dodecyl gallate and Propyl gallate did not show antimicrobial activity against MDR bacteria in the present study but another study reported good antimicrobial activity of both compounds against MRSA [5]. Propyl gallate performed antibacterial activity against non-MDR E. coli, P. aeruginosa and S. typhi [11]. Gram-negative bacteria have specialized cell wall structure, therefore, they are difficult to kill as compared to gram-positive bacteria. The diffusion of antibiotic and active compounds is obstructed due to the presence of periplasmic space and murein layer. Mutation in active efflux pumps out anti-bacterial agent through the efflux pumps, which further promotes the development of intrinsic resistance for gram-negative bacteria [12]. Chemical structure including saturated chain length position and number in the benzene ring of phenolic compounds plays a key role in determining their anti-microbial activity. Phenolic acids had lower antimicrobial activity compared with their butyl and methyl ester [13]. The antimicrobial effect increased with increasing length of the alkyl chain [14].

Hydroxybenzoic and hydroxycinnamic acids occurring in plants exhibit diversity with respect to the number of hydroxyl or methoxy groups. Alkyl gallates disrupt the respiratory mechanism of bacteria by acting as pro-oxidants, which produce free radicles. These RoS cause oxidation of unsaturated fatty acids in the cell membrane, leading to disruption of its structure and function [15]. However, current knowledge on structure-function relationships of the antimicrobial activity of phenolic acids does not account for this diversity of compounds. Para hydroxy benzoic acid was found to be a potent antimicrobial agent against MRSA but the present study exhibited no antimicrobial activity of Parahydroxy benzoic acid and its ethyl and methyl esters against MDR grampositive and gram-negative bacteria [5]. Methyl 4 hydroxy benzoic acid showed weak antimicrobial activity against non-MDR P. aeruginosa, E. coli and S. aureus [16]. Similarly, Vanillic acid exhibited no antimicrobial activity in the present study. Earlier reports displayed antimicrobial activity against MRSA, MDR E. coli and $P$. mirabilus. Antimicrobial activity of Trimethyl gallic acid against non-MDR gram-positive and gram-negative bacteria was reported (350). The previous study explained antimicrobial activity of Syringic acid against MRSA, MDR E. coli and $P$. mirabilus, which supports the results of the present study [17].

The absence of antibacterial activity does not mean that there is no potential of inhibiting microbes. It may be possible that the active compound was not in sufficient quantity or diluted with other non-antimicrobial compounds. Sometimes seasonal variations, geographical area, age of plant and method of extraction also influence the activity of the compound [18]. Extraction techniques are usually based on the chemical nature of compounds and their solubility in polar and non-polar solvents [19].

The approach of using antimicrobial substances that suppress the mechanism of antimicrobial resistance, hence increasing the efficiency of antimicrobial product, is known as synergism [20]. Synergistic combinations of different drugs or with herbal formulations play an important role in treating antibiotic resistance. Alkyl gallates are documented to possess resistance modifying action on various antibiotics against MRSA [21]. Therefore, we used different combinations of antibiotics with Methyl gallate. Our study exhibited strong synergistic combinations of Ciprofloxacin and Amoxycillin with Methyl gallate against MDR E. coli and MRSA, respectively. An earlier study explained synergistic combination of Ciprofloxacin and Methyl gallate against non-MDR S. typhi [22]. There are different mechanisms involved in the augmentation of the antibacterial activity of antibiotics by natural compounds such as interaction on multiple target sites in bacteria; bioavailability and solubility of antibiotics or aimed for a specific bacterial resistance mechanism [23]. These interactions prevent the activity of drugs from enzyme degradation and alterations in transport proteins, thus bypassing the mechanism of antimicrobial resistance [24]. Amoxycillin is a $\beta$-lactam antibiotic that inhibits bacterial cell wall synthesis by binding one or more of the penicillin-binding proteins (PBPs). Stimulation of mecA gene and gene variants resulted in the formation of PBP2a, which attaches to lower affinity with antibiotics and leads to drug resistance [25]. We assume that methyl gallate interferes with the synthesis of PBP2a in cell wall of bacteria. This could be the explanation of synergistic combinations in the present study.

\section{Conclusions}

Our study suggested that phenolic compounds are potential sources of therapeutic substances as compared with the conventional antibiotics that have failed to treat multi drug-resistant infections. Synergistic combinations of Methyl gallate with Ciprofloxocin and Amoxycillin against MDR E. coli and MRSA have been found to be effective against MDR bacteria but detailed mode of action and toxicity profiles are needed to be explored.

\section{Declarations}

\section{Ethical Declaration:}

These studies were conducted after receiving an approval from independent Ethics Committee, ICCBS, UoK No: ICCBS/IEC-008-BC-2015/Protocol/1.0.

\section{Consent for publication:}

Not applicable

\section{Availability of data and material:}

The datasets generated and/or analysed during the current study are not publicly available but are available from the corresponding author on reasonable request.

\section{Declation of Interests:}

All authors have no conflict of interest.

\section{Funding:}




\section{Authors's contribution:}

FZK has designed plan of work and writing, MY, SJ and AH helped in Conduction of work, SF, SJ and AH performed final editing and statistical analysis and Shahana Urooj Kazmi performed Proof reading. All authors read and approved the final manuscript.

\section{Acknowledgement:}

The results described in this paper were part of the PhD thesis of Fouzia Zeeshan Khan. We are highly indebted to Mr. Yousuf for his help in electron microscopy.

\section{References}

1. Adedeji W. The treasure called antibiotics. Ann Ib Postgrad Med. 2016;14(2):56.

2. Sajid M, Prabjeet S, Samoon MH, Balange AK. Effect of dietary chitosan on non-specific immune response and growth of Cyprinus carpio challenged with Aeromonas hydrophila. Int Aquat Res. 2010;2(2):77-85.

3. Petrovska BB. Historical review of medicinal plants' usage. Pharmacogn Rev. 2012;6(11):1.

4. Soelberg J, Davis O, Jäger AK. Historical versus contemporary medicinal plant uses in the US Virgin Islands. J Ethnopharmacol. 2016;192:74-89.

5. Manach C, Scalbert A, Morand C, Rémésy C, Jiménez L. Polyphenols: food sources and bioavailability. Am J Clin Nutr. 2004;79(5):727-47.

6. Haminiuk CW, Maciel GM, Plata-Oviedo MS, Peralta RM. Phenolic compounds in fruits-an overview. IntJ Food Sci. 2012;47(10):2023-44.

7. Venkatesalu V, Gopalan N, Pillai C, Singh V, Chandrasekaran M, Senthilkumar A, et al. In vitro anti-plasmodial activity of some traditionally used medicinal plants against Plasmodium falciparum. Parasitol. Res. 2012;111(1):497-501.

8. Madagundi SD, Pawadshetter MK, Sholapur HP, Habbu P, Biradar SM. A comparative study of isolated flavonoid and different extracts of Caesalpinia pulcherrima (L) Sw. for in vitro immunomodulatory effects on human neutrophils. 怄怄区. 2012;7(4):159-67.

9. Takawale H, Mute V, Awari D, Hukkeri V, Mehta P, Vawhal P. Screening of antiulcer activity of Caesalpinia pulcherrima L. Bark. against aspirin induced ulcer in rats. World J Medical Sci. 2011;6(4):168-72.

10. Khan F YM, Faizi S, Kazmi SU. in vitro inhibition of mdr bacterial isolates by extracts of different parts. Indian JPharm Sci. Res 2015;5(3).

11. Valgas C, Souza SMd, Smânia EF, Smânia Jr A. Screening methods to determine antibacterial activity of natural products. Braz J Microbiol. 2007;38(2):369-80.

12. Ericsson HM, Sherris JC. Antibiotic sensitivity testing. Report of an international collaborative study. ActaPathol Microbiol Scand. 1971(Suppl. 217).

13. Pykett AH. An assessment of the Sensititre method for determining minimum inhibitory and bactericidal concentrations. J Clin Pathol. 1978;31(6):536-8.

14. Farooqui A, Khan A, Borghetto I, Kazmi SU, Rubino S, Paglietti B. Synergistic antimicrobial activity of Camellia sinensis and Juglans regia against multidrug-resistant bacteria. PloS one. 2015;10(2):e0118431.

15. Lorian V. Antibiotics in laboratory medicine: Lippincott Williams \& Wilkins; 2005.

16. Veerappan A, Miyazaki S, Kadarkaraisamy M, Ranganathan D. Acute and subacute toxicity studies of Aegle marmelos Corr., an Indian medicinal plant. Phytomedicine. 2007;14(2-3):209-15.

17. Raskin I, Ribnicky DM, Komarnytsky S, llic N, Poulev A, Borisjuk N, et al. Plants and human health in the twenty-first century. Trends Biotechnol. 2002;20(12):522-31.

18. Simoes M, Bennett RN, Rosa EA. Understanding antimicrobial activities of phytochemicals against multidrug resistant bacteria and biofilms. NatProd Rep. 2009;26(6):746-57.

19. Jiamboonsri P, Pithayanukul P, Bavovada R, Chomnawang MT. The inhibitory potential of Thai mango seed kernel extract against methicillin-resistant Staphylococcus aureus. Molecules. 2011;16(8):6255-70.

20. Shibata H, Kondo K, Katsuyama R, Kawazoe K, Sato Y, Murakami K, et al. Alkyl gallates, intensifiers of $\beta$-lactam susceptibility in methicillin-resistant Staphylococcus aureus. Antimicrob Agents Chemother. 2005;49(2):549-55.

21. Hassoun A, Linden PK, Friedman B. Incidence, prevalence, and management of MRSA bacteremia across patient populations-a review of recent developments in MRSA management and treatment. Crit Care. 2017;21(1):211.

22. Ekaprasada MT, Nurdin H, Ibrahim S, Dachriyanus D. Antibacterial Activity of Methyl Gallate Isolated from the Leaves of Toona sureni. International Journal on Advanced Science, Int J Adv Sci Eng Inf Technol. 2015;5(4):280-2.

23. Sánchez E, Heredia N, Camacho-Corona MdR, García S. Isolation, characterization and mode of antimicrobial action against V ibrio cholerae of methyl gallate isolated from A cacia farnesiana. J Appl Microbiol. 2013;115(6):1307-16.

24. Gangan VD, Dubey RS, Chakraborty CT, Tamhankar AV, Kadam JJ, Singh AC. Ethyl Paraben Derivatives as Future Potential Drug. J chem biol phys sci. 2013;4(1):131.

25. Borges A, Ferreira C, Saavedra MJ, Simoes M. Antibacterial activity and mode of action of ferulic and gallic acids against pathogenic bacteria. Microb Drug Resist. 2013;19(4):256-65.

26. Oladimeji $\mathrm{OH}$, Igboasoiyi AC. Isolation, characterization and antimicrobial analysis of Ethyl gallate and Pyrogallol from Acalypha wilkesiana var. laceacalypha (Muell \& Arg.). Afr J Pharmacol Ther. 2014;3(3). 
27. Zgurskaya HI, Lopez CA, Gnanakaran S. Permeability barrier of Gram-negative cell envelopes and approaches to bypass it. ACS Infect Dis. 2015;1(11):512-22.

28. Albarran G, Boggess W, Rassolov V, Schuler RH. Absorption spectrum, mass spectrometric properties, and electronic structure of 1, 2-benzoquinone. J. Phys. Chem. A 2010;114(28):7470-8.

29. Merkl R, Hradkova I, Filip V, Smidrkal J. Antimicrobial and antioxidant properties of phenolic acids alkyl esters. Czech J Food Sci. 2010;28(4):275-9.

30. Kubo I, Fujita K-i, Nihei K-i, Nihei A. Antibacterial activity of akyl gallates against Bacillus subtilis. J. Agric. Food Chem. 2004;52(5):1072-6.

31. Herman A, Herman AP, Domagalska BW, Młynarczyk A. Essential oils and herbal extracts as antimicrobial agents in cosmetic emulsion. Indian J. Microbiol. 2013;53(2):232-7.

32. Alves MJ, Ferreira IC, Froufe HJ, Abreu R, Martins A, Pintado M. Antimicrobial activity of phenolic compounds identified in wild mushrooms, SAR analysis and docking studies. J. Appl. Microbiol. 2013;115(2):346-57.

33. Abdel-Massih R, Abdou E, Baydoun E, Daoud Z. Antibacterial activity of the extracts obtained from Rosmarinus officinalis, Origanum majorana, and Trigonella foenum-graecum on highly drug-resistant gram negative bacilli. Journal of Botany. 2010;2010.

34. Cseke LJ, Kirakosyan A, Kaufman PB, Warber S, Duke JA, Brielmann HL. Natural products from plants: CRC press; 2016.

35. Shahverdi A, Monsef-Esfahani H, Tavasoli F, Zaheri A, Mirjani R. Trans-cinnamaldehyde from Cinnamomum zeylanicum bark essential oil reduces the clindamycin resistance of Clostridium difficile in vitro. Journal of food science. 2007;72(1):S055-S8.

36. Miklasińska-Majdanik M, Kępa M, Wojtyczka R, Idzik D, Wąsik T. Phenolic Compounds Diminish Antibiotic Resistance of Staphylococcus Aureus Clinical Strains. International journal of environmental research and public health. 2018;15(10):2321.

37. Choi J-G, Kang O-H, Lee Y-S, Oh Y-C, Chae H-S, Jang H-J, et al. In vitro activity of methyl gallate isolated from galla rhois alone and in combination with ciprofloxacin against clinical isolates of salmonella. Journal of microbiology and biotechnology. 2008;18(11):1848-52.

38. Daglia M. Polyphenols as antimicrobial agents. Current opinion in biotechnology. 2012;23(2):174-81.

39. Yeh PJ, Hegreness MJ, Aiden AP, Kishony R. Drug interactions and the evolution of antibiotic resistance. Nature Reviews Microbiology. $2009 ; 7(6): 460$.

40. Pinho MG, Filipe SR, de Lencastre Hn, Tomasz A. Complementation of the essential peptidoglycan transpeptidase function of penicillin-binding protein 2 (PBP2) by the drug resistance protein PBP2A in Staphylococcus aureus. Journal of bacteriology. 2001;183(22):6525-31.

\section{Tables}

\section{Table 1A: Antimicrobial Activity of Phenolic Compounds}

\begin{tabular}{|c|c|c|c|c|c|c|c|c|c|c|c|c|c|}
\hline \multirow[t]{2}{*}{ S.No } & \multirow[t]{2}{*}{ Compounds } & \multicolumn{2}{|l|}{ MRSA } & \multicolumn{2}{|l|}{ VRSA } & \multicolumn{2}{|c|}{$\begin{array}{l}\text { S. aureus ATCC } \\
29213\end{array}$} & \multicolumn{2}{|l|}{ E. coli } & \multicolumn{2}{|c|}{$\begin{array}{l}\text { E. coli ATCC } \\
25922\end{array}$} & \multicolumn{2}{|c|}{ K. pneumoniae } \\
\hline & & $\begin{array}{l}\mathrm{MIC} \\
(\mu \mathrm{g} / \mathrm{ml})\end{array}$ & $\begin{array}{l}\mathrm{MBC} \\
(\mu \mathrm{g} / \mathrm{ml})\end{array}$ & $\begin{array}{l}\mathrm{MIC} \\
(\mu \mathrm{g} / \mathrm{ml})\end{array}$ & $\begin{array}{l}\mathrm{MBC} \\
(\mu \mathrm{g} / \mathrm{ml})\end{array}$ & $\begin{array}{l}\mathrm{MIC} \\
(\mu \mathrm{g} / \mathrm{ml})\end{array}$ & $\begin{array}{l}\mathrm{MBC} \\
(\mu \mathrm{g} / \mathrm{ml})\end{array}$ & $\begin{array}{l}\mathrm{MIC} \\
(\mu \mathrm{g} / \mathrm{ml})\end{array}$ & $\begin{array}{l}\mathrm{MBC} \\
(\mu \mathrm{g} / \mathrm{ml})\end{array}$ & $\begin{array}{l}\mathrm{MIC} \\
(\mu \mathrm{g} / \mathrm{ml})\end{array}$ & $\begin{array}{l}\mathrm{MBC} \\
(\mu \mathrm{g} / \mathrm{ml})\end{array}$ & $\begin{array}{l}\mathrm{MIC} \\
(\mu \mathrm{g} / \mathrm{ml})\end{array}$ & $\begin{array}{l}\mathrm{MBC} \\
(\mu \mathrm{g} / \mathrm{ml})\end{array}$ \\
\hline 1 & Gallic acid & 500 & 1000 & 1000 & 2000 & 500 & 1000 & 500 & 1000 & 500 & 1000 & 500 & 1000 \\
\hline 2 & $\begin{array}{l}\text { Methyl } \\
\text { gallate }\end{array}$ & 125 & 250 & 250 & 500 & 125 & 500 & 125 & 250 & 250 & 250 & 125 & 125 \\
\hline 3 & Ethyl gallate & 1000 & 2000 & 1000 & 2000 & 1000 & $>2000$ & 500 & 1000 & 500 & 1000 & 1000 & 2000 \\
\hline 4 & $\begin{array}{l}\text { Dodecyl } \\
\text { gallate }\end{array}$ & Nil & Nil & Nil & Nil & Nil & Nil & Nil & Nil & Nil & Nil & Nil & Nil \\
\hline 5 & $\begin{array}{l}\text { Propyl } \\
\text { gallate }\end{array}$ & Nil & Nil & Nil & Nil & Nil & Nil & Nil & Nil & Nil & Nil & Nil & Nil \\
\hline 6 & $\begin{array}{l}\text { Syringic } \\
\text { acid }\end{array}$ & 1000 & 2000 & 1000 & 2000 & 1500 & 3000 & 750 & 750 & 1000 & 1000 & 1000 & 2000 \\
\hline 7 & Vanillic acid & Nil & Nil & Nil & Nil & Nil & Nil & Nil & Nil & Nil & Nil & Nil & Nil \\
\hline 8 & $\begin{array}{l}\text { Parahydroxy } \\
\text { benzoic acid }\end{array}$ & Nil & Nil & Nil & Nil & Nil & Nil & Nil & Nil & Nil & Nil & Nil & Nil \\
\hline 9 & $\begin{array}{l}\text { Ethyl } 4 \\
\text { hydroxy } \\
\text { benzoic acid }\end{array}$ & Nil & Nil & Nil & Nil & Nil & Nil & Nil & Nil & Nil & Nil & Nil & Nil \\
\hline 10 & $\begin{array}{l}\text { Methyl } 4 \\
\text { hydroxy } \\
\text { benzoic acid }\end{array}$ & Nil & Nil & Nil & Nil & Nil & Nil & Nil & Nil & Nil & Nil & Nil & Nil \\
\hline 11 & $\begin{array}{l}\text { Gallic acid } \\
\text { tri methyl } \\
\text { ether }\end{array}$ & 1000 & 2000 & 1000 & 2000 & 1000 & 1000 & 500 & 1000 & 1000 & 2000 & 2000 & $>4000$ \\
\hline
\end{tabular}

Table 1B: Antimicrobial Activity of Phenolic Compounds 


\begin{tabular}{|c|c|c|c|c|c|c|c|c|c|c|c|}
\hline \multirow[t]{2}{*}{ S.No } & \multirow[t]{2}{*}{ Compounds } & \multicolumn{2}{|l|}{ S. typhi } & \multicolumn{2}{|c|}{ S. typhi ATCC 27853} & \multicolumn{2}{|c|}{$P$. aeruginosa } & \multicolumn{2}{|c|}{ Acinetobacter spp } & \multicolumn{2}{|c|}{ P. mirabilis } \\
\hline & & $\begin{array}{l}\text { MIC } \\
(\mu \mathrm{g} / \mathrm{ml})\end{array}$ & $\begin{array}{l}\mathrm{MBC} \\
(\mu \mathrm{g} / \mathrm{ml})\end{array}$ & $\begin{array}{l}\text { MIC } \\
(\mu \mathrm{g} / \mathrm{ml})\end{array}$ & $\begin{array}{l}\mathrm{MBC} \\
(\mu \mathrm{g} / \mathrm{ml})\end{array}$ & $\begin{array}{l}\mathrm{MIC} \\
(\mu \mathrm{g} / \mathrm{ml})\end{array}$ & $\begin{array}{l}\mathrm{MBC} \\
(\mu \mathrm{g} / \mathrm{ml})\end{array}$ & $\begin{array}{l}\text { MIC } \\
(\mu \mathrm{g} / \mathrm{ml})\end{array}$ & $\begin{array}{l}\text { MBC } \\
(\mu \mathrm{g} / \mathrm{ml})\end{array}$ & $\begin{array}{l}\text { MIC } \\
(\mu \mathrm{g} / \mathrm{ml})\end{array}$ & $\begin{array}{l}\mathrm{MBC} \\
(\mu \mathrm{g} / \mathrm{ml})\end{array}$ \\
\hline 1 & Gallic acid & 500 & 1000 & 500 & 1000 & 1000 & 1000 & 1000 & $>2000$ & 1000 & $>2000$ \\
\hline 2 & Methyl gallate & 250 & 500 & 125 & 250 & 250 & 500 & 250 & 250 & 250 & $>500$ \\
\hline 3 & Ethyl gallate & 1000 & 1000 & 1000 & 2000 & 1000 & 2000 & 2500 & $>5000$ & 2500 & 5000 \\
\hline 4 & Dodecyl gallate & Nil & Nil & Nil & Nil & Nil & Nil & Nil & Nil & Nil & Nil \\
\hline 5 & Propyl gallate & Nil & Nil & Nil & Nil & Nil & Nil & Nil & Nil & Nil & Nil \\
\hline 6 & Syringic acid & 750 & 1500 & 500 & 1000 & 1000 & 1000 & 2000 & 2000 & 2000 & 2000 \\
\hline 7 & Vanillic acid & Nil & Nil & Nil & Nil & Nil & Nil & Nil & Nil & Nil & Nil \\
\hline 8 & $\begin{array}{l}\text { Parahydroxy benzoic } \\
\text { acid }\end{array}$ & Nil & Nil & Nil & Nil & Nil & Nil & Nil & Nil & Nil & Nil \\
\hline 9 & $\begin{array}{l}\text { Ethyl } 4 \text { hydroxy } \\
\text { benzoic acid }\end{array}$ & Nil & Nil & Nil & Nil & Nil & Nil & Nil & Nil & Nil & Nil \\
\hline 10 & $\begin{array}{l}\text { Methyl } 4 \text { hydroxy } \\
\text { benzoic acid }\end{array}$ & Nil & Nil & Nil & Nil & Nil & Nil & Nil & Nil & Nil & Nil \\
\hline 11 & $\begin{array}{l}\text { Gallic acid tri methyl } \\
\text { ether }\end{array}$ & 1000 & 2000 & 500 & 1000 & 1000 & 2000 & 2500 & 2500 & 2000 & $>5000$ \\
\hline
\end{tabular}

Table 2: Synergistic Combinations of Ciprofloxocin with Methyl gallate against MDR E. coli

\begin{tabular}{|c|c|c|c|c|c|c|}
\hline \multirow[t]{2}{*}{ MDR E. coli strains } & \multicolumn{2}{|c|}{$\begin{array}{l}\text { MICs of Ciprofloxocin } \\
\mu \mathrm{g} / \mathrm{ml}\end{array}$} & \multicolumn{2}{|c|}{$\begin{array}{l}\text { MICs of Methyl gallate } \\
\mu \mathrm{g} / \mathrm{ml}\end{array}$} & \multicolumn{2}{|c|}{ Fractional Inhibitory Concentration Index } \\
\hline & In combination & Alone & In combination & Alone & (FICl) & Average $\mathrm{FICl}$ \\
\hline 1 & 0.125 & 512 & 15.6 & 125 & 0.125 & \\
\hline 2 & 0.5 & 512 & 15.6 & 125 & 0.125 & \\
\hline 3 & 0.125 & 256 & 31.25 & 500 & 0.062 & $0.137 \pm 0.11$ \\
\hline 4 & 0.125 & 512 & 62.5 & 250 & 0.250 & \\
\hline 5 & 0.5 & 256 & 31.25 & 125 & 0.251 & \\
\hline
\end{tabular}

Table 3: Synergistic Combinations of Amoxycillin with Methyl gallate against MRSA

\begin{tabular}{|lllllll|}
\hline MRSA Strains & \multicolumn{2}{l}{$\begin{array}{l}\text { MICs of Amoxycillin } \\
\mu \mathbf{g} / \mathbf{m l}\end{array}$} & $\begin{array}{l}\text { MICs of Methyl gallate } \\
\boldsymbol{\mu g} / \mathbf{m l}\end{array}$ & Fractional Inhibitory Concentration Index \\
\cline { 2 - 7 } & In combination & Alone & In combination & Alone & $(\mathbf{F I C l )}$ & Average FICl \\
\hline 1 & 0.125 & 256 & 31.25 & 250 & 0.125 & \\
\hline 2 & 0.0625 & 256 & 31.25 & 250 & 0.125 & $0.225 \pm 0.162$ \\
\hline 3 & 0.125 & 128 & 125 & 500 & 0.250 & \\
\hline 5 & 0.125 & 128 & 125 & 250 & 0.500 & \\
\hline
\end{tabular}

\section{Figures}




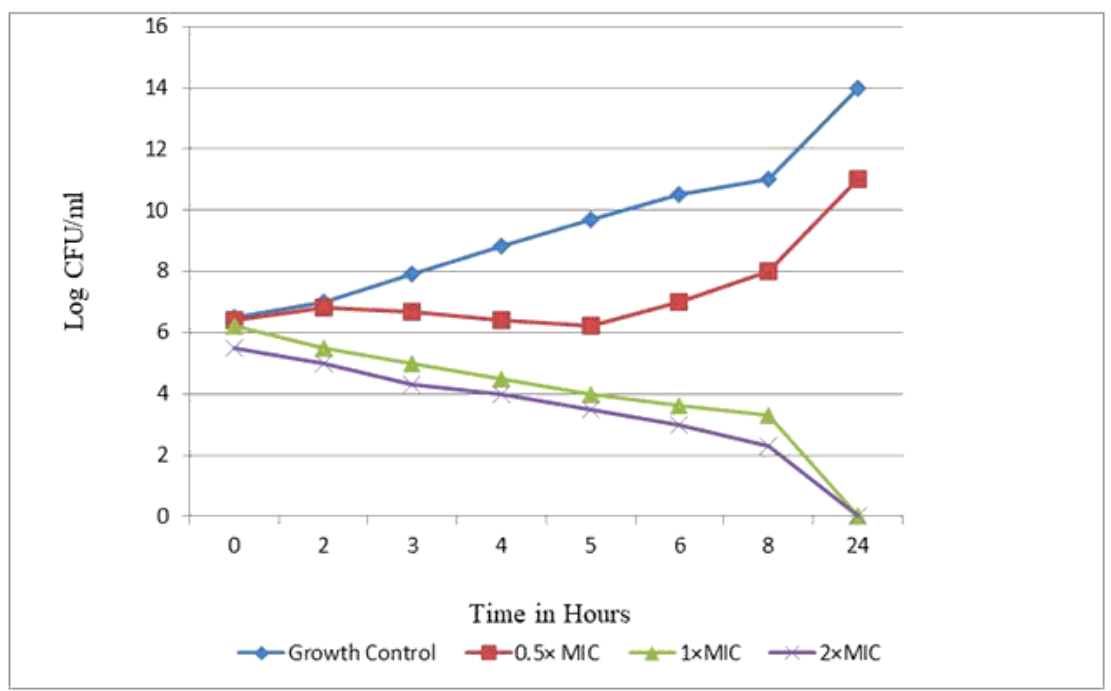

Figure 1

Effects of Methyl gallate on Growth Kinetics of MRSA Growth Kinetics Curve of Methicillin Resistant Staphylococcus aureus (MRSA) with three different concentration of Methyl gallate. Growth control without Methyl gallate was also included for comparison. Decreases in CFU at 2×Log10 was taken as significant. Results are interpreted as an average and standard deviation of three different sets of experiments. P<0.05 was calculated by one-way ANOVA.

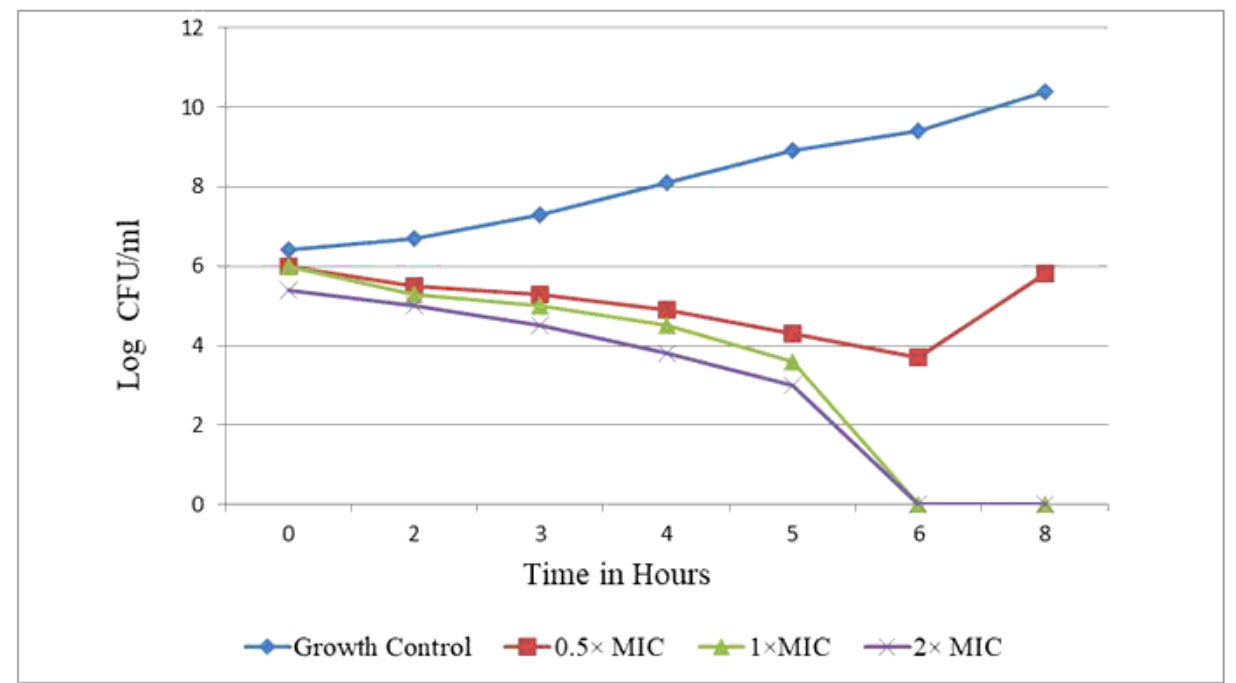

\section{Figure 2}

Effects of Methyl gallate on Growth Kinetics of S. aureus ATCC 29213 Growth Kinetics Curve of Staphylococcus aureus ATCC 29213 with three different concentration of Methyl gallate. Growth control without Methyl gallate was also included for comparison. Decreases in CFU at $2 \times$ Log 10 was taken as significant. Results are interpreted as an average and standard deviation of three different sets of experiments. P<0.05 was calculated by one-way ANOVA. 


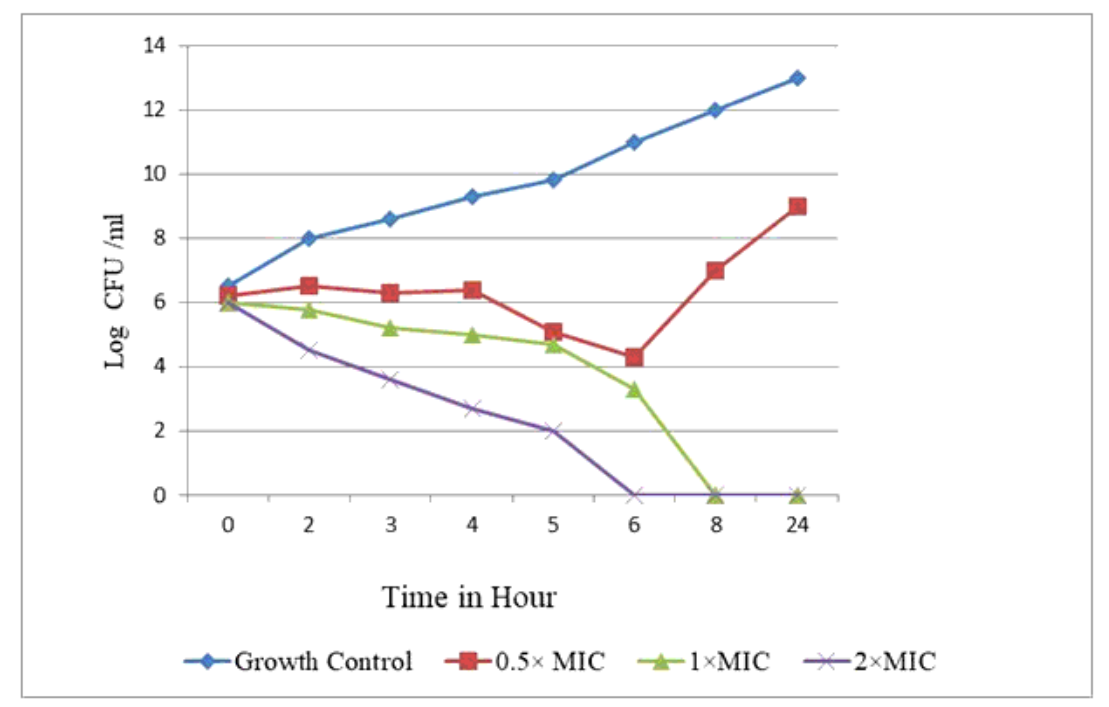

\section{Figure 3}

Effects of Methyl gallate on Growth Kinetics of E. coli ATCC 25922 Growth Kinetics Curve of E. coli ATCC 25922 with three different concentration of Methyl gallate. Growth control without Methyl gallate was also included for comparison. Decreases in CFU at $2 \times$ Log 10 was taken as significant. Results are interpreted as an average and standard deviation of three different sets of experiments. $P<0.05$ was calculated by one-way ANOVA

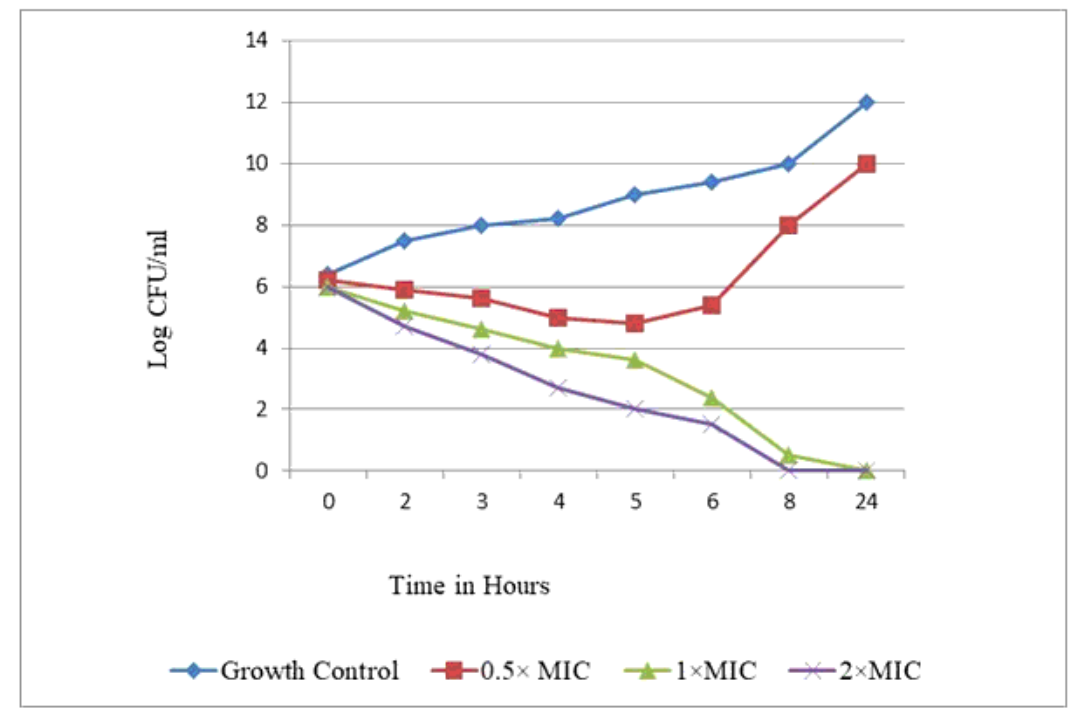

\section{Figure 4}

Effects of Methyl gallate on Growth Kinetics of MDR E. coli Growth Kinetics Curve of MDR E. coli with three different concentration of Methyl gallate. Growth control without Methyl gallate was also included for comparison. Decreases in CFU at 2×Log10 was taken as significant. Results are interpreted as an average and standard deviation of three different sets of experiments. $\mathrm{P}<0.05$ was calculated by one-way ANOVA 


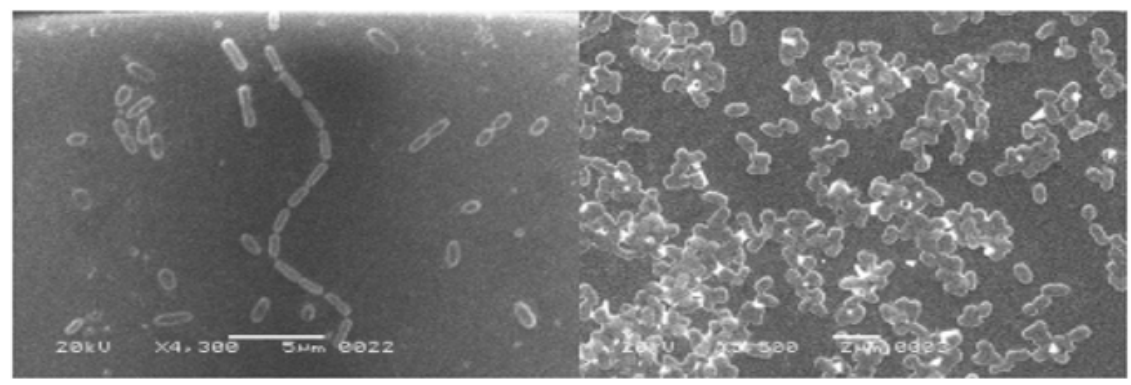

A

B

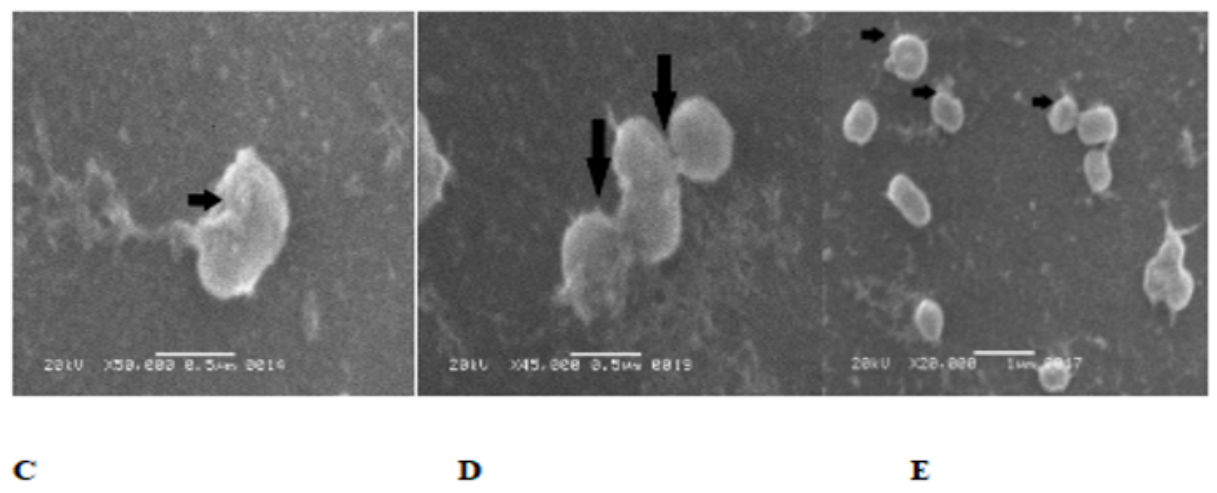

\section{Figure 5}

Effect of Methyl gallate on Cell Morphology of MDR E. coli Scanning Electron Microscopy was performed to analyse change in cell morphology of MDR E. coli after treatment with Methyl gallate. A and B (control cells without Methyl gallate). C, D and E showed changes in cell morphology after incubating 24 hours at $37^{\circ} \mathrm{C}$ with subinhibitory concentration of Methyl gallate.

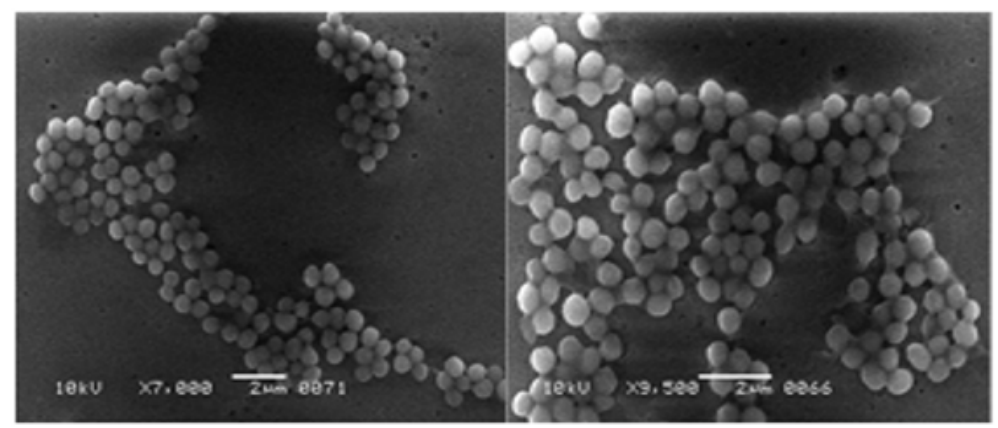

A

$\mathbf{B}$
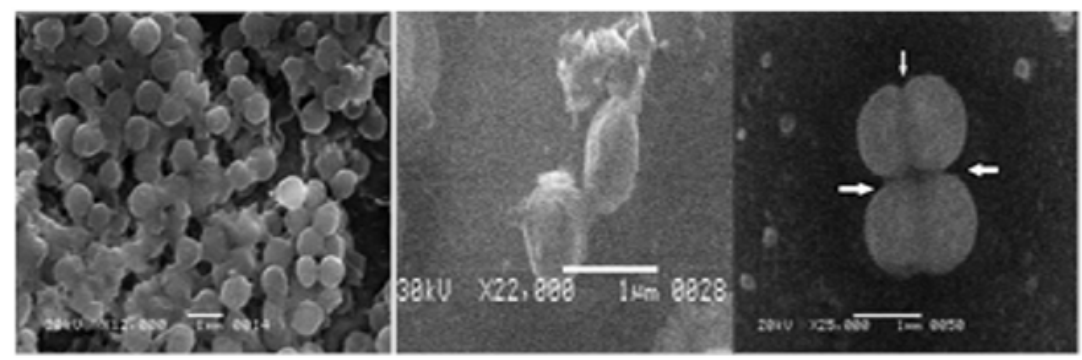

C

D

E

Figure 6 
Effect of Methyl gallate on Cell Morphology of MRSA Scanning Electron Microscopy was performed to analyse change in cell morphology of Methicillin Resistant Staphylococcus aureus after treatment with Methyl gallate. A and B (control cells without Methyl gallate.). C, D, E and F showed changes in cell morphology after incubating 24 hours at $37^{\circ} \mathrm{C}$ with subinhibitory concentration of Methyl gallate 